\title{
Assessment of the rates of thiocyanate in treated and untreated red and brown finger millet (Eleusine coracana) cultivated in Mogotio Area, Baringo County, Kenya
}

\author{
SILVA JERONO CHEBET, MILDRED NAWIRI", JANE MURUNGI \\ Department of Chemistry, Kenyatta University. P.O. Box 43844, -00100, Nairobi, Kenya. "email: mildredoyugi@yahoo.com
}

Manuscript received: 6 March 2018. Revision accepted: 21 June 2018.

\begin{abstract}
Chebet SJ, Nawiri M, Murungi J. 2018. Assessment of the rates of thiocyanate in treated and untreated red and brown finger millet (Eleusine coracana) cultivated in Mogotio Area, Baringo County, Kenya. Trop Drylands 2: 28-34. Finger millet (Eleusine coracana) is a significant African primary diet crop in the tropics. But, the plant contains cyanogenic glycosides which can be easily altered to thiocyanate, impeding the absorption of iodine and eventually causing goiter. People of Mogotio, Kenya usually cultivate the red and brown varieties of finger millet. Therefore, this study aimed to assess the rate of thiocyanate in treated and untreated finger millet in Mogotio so as to mitigate goiter risks in the region. The rates of thiocyanate were examined from the finger millet in the form of dried, germinated or immersed beans, or in the form of fresh, fermented or cooked flour. The green and dried leaves of the plant were also examined for thiocyanate. Samples of the red and brown varieties of finger millet were arbitrarily picked out from the cultivators in the area. Thiocyanate content was examined utilizing UV-VIS spectrophotometric detection. ANOVA and independent T-test were utilized to analyze data. SNK test was utilized to do the separation of means. The results showed that the rates of thiocyanate content in the red finger millet were between $43.48 \pm 1.56$ to $4.28 \pm 0.5 \mathrm{mg} / \mathrm{kg}$ with the highest rates was in fresh dried beans followed by germinated ones and the lowest rates were in cooked flour. While in the brown finger millet, it was between $53.30 \pm 0.78$ to $4.96 \pm 0.40 \mathrm{mg} / \mathrm{kg}$ with the highest rates was in germinated beans and the lowest rates were in cooked flour. Green leaves held $31.69 \pm 0.71 \mathrm{mg} / \mathrm{kg}$ while the dried ones held $8.80 \pm 0.14 \mathrm{mg} / \mathrm{kg}$. The results showed significant dissimilarities between the rates in the beans and that of in the flour ( $\mathrm{p}<0.001)$. They also showed that the thiocyanate content in finger millet samples was within the recommended rates $(100 \mathrm{mg} / \mathrm{kg}), \mathrm{but}$ the frequency of intake may still give a risk to health. Therefore, it is suggested to encourage the cooking of finger millet before processing as this treatment decreases thiocyanate rates.
\end{abstract}

Keywords: Eleusine coracana, Kenya, Mogotio, red and brown finger millet, treated and untreated

\section{INTRODUCTION}

Goiter is an intumescence on the thyroid gland. Its establishment is critically associated with the balance between iodine and thiocyanate. Adwok (2006) reported that more than $5 \%$ of the population of the world suffer from goiters. Many of these are related to various diseases and are considered a crucial communal health issue. Gaitan (1989) stated that although 300 million people with goiter settle in less highly developed countries where iodine inadequacy is usual, 100 million individuals with goiter settle in more highly developed countries where goiter keeps on to happen in particular regions, despite iodine prophylaxis. Elnour et al. (2000) claimed that in Africa, goiter is endemic in many countries such as Congo, Uganda, Kenya, and Sudan, in which the commonness is as high as $81 \%$ in some parts of these countries.

Toure et al. stated that a goitrogen is discovered in some African diets (2003). Millet (Eleusine, Pennisetum, Setaria, Echinochloa, and Paspalum) is a fount of thiocyanate whose goitrogenic influences are additive to those of the C-glycosyl flavanol (C-GF) (Makokha 2002). Thiocyanate and isothiocyanate have been shown as the goitrogenic principles of cyanogenic plants (Chandra et al. 2004). Millet and sorghum are founts of dhurrin which upon hydrolysis produce cyanide, sugar and ketone or aldehyde (Saidu 2004). After intake, these glycosides can be easily altered to thiocyanate by widespread glycosidases and the sulfurtransferase enzyme (Chandra et al. 2004). The highly potent thiocyanate is involved in the high cases of goiter in millet and cassava eating inhabitants (Toure et al. 2003). The intake of pearl millet is regarded as one of the factors responsible for high occurrences of goiter in rural inhabitants (Gaitan 1989). In Sri Lanka, the goitrogenic influences of the commonly utilized finger millet (Eleusine coracana) were accredited to three types of C-GF. Epidemiological attestation implies that millet might have significant role in the etiology of endemic goiter. In Sudan, a traditional fermentation procedure of two pearl millet cultivars cultivated in the area altered their effects on the weight of the thyroid gland and thyroid hormone profile in rats (Elnour et al. 2000). Millet's goitrogenic agent is obviously related to the bran and endosperm fractions and might be connected to the beans' high proportion of minerals (Klopfenstein et al. 2012). Nonetheless, the plant is a major source of energy, protein, vitamins, and minerals such as potassium, iron, zinc, copper and manganese (Ocheme 2007).

Before being cooked, millet can be treated by desiccation, immersing, germinating and fermentation 
(Ikemefuna 1994). Dried beans are usually crunched to fresh flour which is utilized directly to make thin or thick porridge (cooked flour) or to be fermented before cooking process. Steeping of cereal beans in water followed by germinating them is a well-known household practice in developing countries including Kenya (Chove and Mamiro 2010). Sprouting decreases the high viscosity and waterbinding characteristic of starch-based porridges. As soon as the bean seeds are dried, changes happen to result in partial breakdown of storage components, such as starch and proteins. The starch nature of the non-germinated beans enables these foods to absorb so much water, yielding a thick porridge (Onyeka and Dibia 2002). Dilution of the porridge enhances bulk and causes the diet more arduous for infants to consume in one sitting. The bulkiness of the porridge restricts sufficient amount of nutrient consumption by the infants. Thus, germination is mainly utilized to lower dietary bulk in beans because it converts remarkable amounts of starch, which is principally responsible for the viscosity in bean gruels, to sugars and short-chain oligosaccharides. These methods of processing, however, affect thiocyanate rates (Traoré et al. 2004).

Finger millet is the second most significant diet plant in Mogotio, Kenya after maize. Mogotio is located in the lower end of Baringo County at 900-1000 m above sea level. The area is mainly semi-dry land. Annual rainfall in this zone is from 400 to $750 \mathrm{~mm}$. The little and erratic rainfall limits successful dryland cultivation to droughtresistant plants such as E. coracana and sorghum (Peter 1992). Finger millet varieties are based on their bean colors from white, orange, red, brown, purple to almost black, but farmers in the area plant the red and the brown varieties. Because of the serious drought, International Crops Research Institute for the Semi-arid Tropics (ICRISAT) together with Egerton University has produced the advanced varieties of finger millet to be cultivated in the area during the March and June rains (ICRISAT 2011). Millet is peeled and milled to produce flours, grits, and peeled whole beans. These products are utilized to prepare primary foods such as thin and thick porridges, bread and steam cooked products. The bean is also utilized to make alcoholic beverages, non-alcoholic beverages, and snacks. The husked bean of the plant has a nutty flavor and can be consumed whole after being roasted or cooked. The green, dry leaves and the straw are utilized as animal feed so that the whole plant is utilized (Tatham et al. 1996). Despite cases of goiter recounted in Mogotio, finger millet keeps on to be one of the favorite diet plants. As such this calls for investigation of thiocyanate rates in finger millet cultivated in this region.

The objectives of this research were: (i) To ascertain concentration of thiocyanate in the freshly dried, germinated and immersed beans of the red and brown finger millet from Mogotio in Baringo County. (ii) To ascertain the concentration of thiocyanate in the fresh, fermented and cooked flour of the red and brown finger millet from Mogotio in Baringo County. (iii) To ascertain the concentration of thiocyanate in the green and dried leaves of the red and brown finger millet from Mogotio in Baringo County.

\section{MATERIALS AND METHODS}

\section{Research design}

The experimental arrangement included sampling of the red and brown finger millet, sample processing which involved drying, germinating, immersing, cooking and fermentation and analysis of thiocyanate rates.

\section{Sample collection}

Random sampling was employed to pick out the cultivators in Mogotio, Baringo County, Kenya (Figure 1). Sampling of the red and brown finger millet beans was carried out in 2012 and 2013 between the months of October and December during harvesting time. Sampling of the beans was carried out two times every month during the three months. About $4.0 \mathrm{~kg}$ of each of the red and brown finger millet beans were sampled. Two months old green leaves were also gathered from the same cultivators between June and August 2013. The samples were put in different well-labeled plastic bags and brought to Kenyatta University, Chemistry laboratory.

\section{Chemicals and reagents}

Analytical grade chemicals were utilized in the analysis. The chemicals comprised potassium thiocyanate (KSCN), de-ionized water, $\mathrm{HNO}_{3} \quad(65 \%$ w/v), Trichloroacetic acid, saturated bromine water, Arsenous trioxide, pyridine, benzidine/phenyl, and hydrochloride.

\section{Cleaning of apparatus}

All glassware was immersed overnight in $10 \%$ analytical grade nitric acid, laved with detergent and rinsed with de-ionized water before being desiccated in an oven at $105{ }^{\circ} \mathrm{C}$. Plastic bottles were thoroughly laved with detergent and also rinsed with de-ionized water then dried in open racks.

\section{Preparation of the standard solution}

Thiocyanate stock solution was set up by dissolving $1.68 \mathrm{~g}$ potassium thiocyanate in $100 \mathrm{ml}$ purified water and then diluted to 1 liter to give $1000 \mu \mathrm{g} / \mathrm{ml}$ (1000 ppm) thiocyanate. The stock solution was stored in plastic bottles and was labeled appropriately. Working standards (1-15 ppm) were freshly set up each time analysis was performed.

\section{Sample preparation}

Finger millet beans were cleansed by winnowing to remove dust and other extraneous materials. Unviable and broken beans were handpicked. The beans were then separated into three portions and handled as given below. 


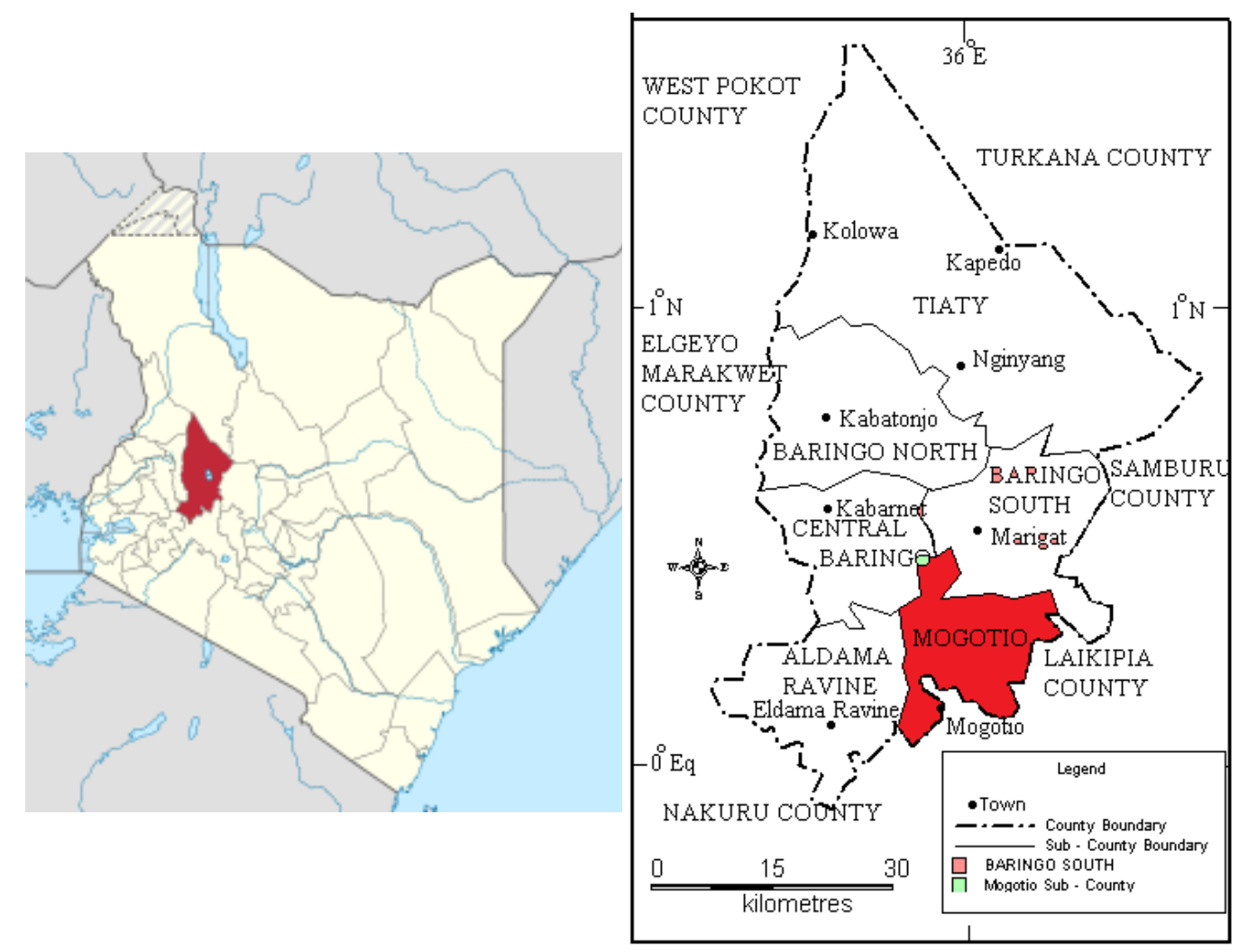

Figure 1. Study site in Mogotio Area, Baringo County, Kenya

\section{Preparation of the freshly dried beans}

The cleansed red and brown finger millet beans were spread on clean trays and sun-dried for 12 hours (Mbithi et al. 2002).

\section{Sprouting of beans}

A hundred grams of laved finger millet beans were put in large Petri-dishes, which were covered on top with perforated aluminum foil. Germination was followed at intervals of 12 hours to 72 hours at $30^{\circ} \mathrm{C}$. After germinating, the beans were sun-dried and milled along with the rootlets to become fine particles and stored in labeled polyethylene bags awaiting thiocyanate extraction (Mbithi et al. 2002).

\section{Soaking of beans}

About a hundred grams each of the red and brown finger millet beans were immersed in purified water (1: 2 $\mathrm{w} / \mathrm{v}$, beans to water) for 900 minutes. The water was drained and the beans were displaced to large Petri-dishes then sun-dried for 6 hours. The procedure was done again and the beans were immersed for 10 minutes, 30 minutes, and 60 minutes respectively (Chove and Mamiro 2010).

\section{Preparation of fresh flour}

The dried beans of the red and brown finger millet were milled into fine flour then wrapped up in polyethylene bags with weights of $100 \mathrm{~g}$ and stocked at room temperature awaiting extraction.

\section{Fermentation of flour}

A hundred grams of flour set up in the previous step was mixed with $200 \mathrm{ml}$ of water and then kneaded to form dough. It was then left to ferment for 3 days at room temperature prior to thiocyanate extraction (Asegbeloyin and Onyimonyi 2007).

\section{Cooked flour (porridge) preparation}

A hundred grams of the fresh flour set up in the previous step was put in a $500 \mathrm{ml}$ beaker and $200 \mathrm{ml}$ of water was poured in to make slurry. The mixture was stirred continuously with a glass rod until it was boiled for 5 minutes. The cooked mixture was immediately cooled in an ice bath for 30 minutes then kept in a tightly closed plastic container awaiting extraction of thiocyanate. The procedure was repeated but for the next repeated procedure, the porridge was left to boil for 10 minutes and 30 minutes respectively (Adamafio and Ankrah 2009).

\section{Preparation of the green and dried leaves}

The green leaves of the red and brown finger millet were cleansed with purified water. The green leaves were placed in a clean mortar then ground with a pestle to produce an extract that was utilized in section 3.7. The dried leaves were set up by air-drying the green leaves then they were ground to form a fine powder.

\section{Extraction and determination of thiocyanate}

Two grams each of the red and brown finger millet samples (beans, flour, and leaves) set up in the previous 
steps was weighed and displaced into a distillation flask, to which $20 \mathrm{ml}$ of purified water was poured. Trichloroacetic acid solution $(20 \% \mathrm{w} / \mathrm{v})$ was poured into digest and precipitate proteins. The samples were then refluxed eventually at room temperature for 2 hours. The dispersal of the tissue was gained by intense shaking then centrifuged for 10 minutes at $1000 \mathrm{rpm}$. The supernatant comprising thiocyanate was poured into $50 \mathrm{ml}$ clean dried volumetric flask and then liquefied to the mark with purified water. It was then displaced into separate plastic bottles, labeled and suitably stocked until the time for analysis (Chandra et al. 2004).

Following the method of Aldridge, the prepared sample extracts were examined for thiocyanate (Chandra et al. 2004). Saturated bromine water and $4 \%$ arsenous trioxide were poured into the extract followed by the addition of pure redistilled pyridine. Then, 2\% phenyl-diamine hydrochloride solution was poured into it and it was left for 30 minutes at room temperature to allow for color development. The absorbance of the sample was read at a wavelength of $525 \mathrm{~nm}$ on the UV-VIS spectrophotometer (Cecil CE- 2041, 2000 series) (Chandra et al. 2004). The concentration of thiocyanate in the finger millet in $\mu \mathrm{g} / \mathrm{ml}$ was immediately interpolated from the thiocyanate calibration curve.

\section{Method of validation}

To ascertain the exactness of the procedure, a recovery test was carried out. The recovery test was conducted by spiking a known amount of thiocyanate into a test portion of the sample and analyzing the spiked test portion along with the original sample.

\section{Data analysis}

To measure the dissimilarity of the concentration of thiocyanate in the various forms of the red and brown varieties of $E$. coracana subjected to different treatments, data was examined utilizing ANOVA test. Independent ttest was utilized to compare the mean values between the red and brown finger millet. The comparison of means was conducted by SNK test. Whenever a remarkable dissimilarity existed, the means were compared at $\mathrm{p}=0.05$ significance level.

\section{RESULTS AND DISCUSSION}

\section{Method validation}

\section{Regression analysis}

Regression analysis was utilized to assess the linearity of the formed calibration curve. The absorbance readings and concentration of the standard were utilized to appraise the correlation coefficient (r). The calibration curve was set up by a plot of absorbance readings (y axis) against the corresponding concentration (x-axis) of the standard.

$\mathrm{R}^{2}$ value from the formed calibration curve $\mathrm{y}=0.018 \mathrm{x}-$ 0.001 was 0.9992 (Figure 2) indicating that there was an excellent correlation between concentration and absorbance.

\section{Recovery test}

The percentage recovery was appraised utilizing the following equation (EURACHEM guide 1998).

$$
\% \text { Recovery }=\frac{\mathrm{SSR}-\mathrm{USR}}{\mathrm{USR}} \times 100
$$

Where

$\mathrm{SSR}=$ Spiked sample result

$\mathrm{USR}=$ Unspiked sample result

The percentage recovery from the spiked sample (Table 1) was between $90-99.80 \%$, while RSD was $3.65-5.01 \%$ and it was within the acceptable range for thiocyanate (Cardoso et al. 2004). This ensures that the method is of good precision and fits for analysis of the above parameter.

\section{Rates of thiocyanate in finger millet beans}

The rates of thiocyanate examined utilizing UV-Vis spectrophotometer are introduced and considered in the following subsections. The rates of thiocyanate in the fresh dried, germinated and immersed beans of the red and brown finger millet are presented in Tables 2 and 3.

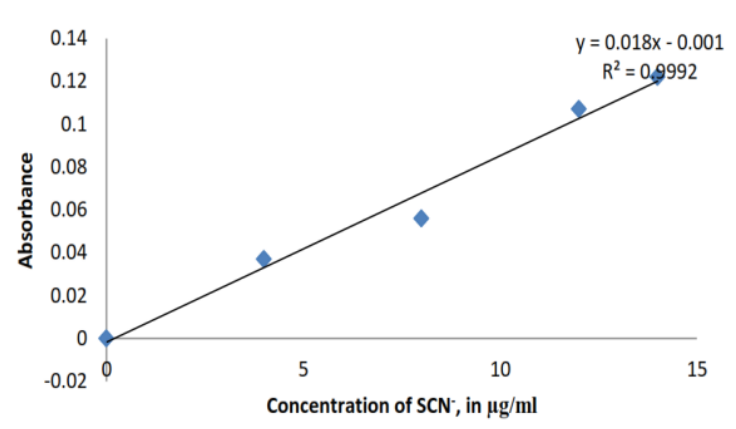

Figure 2. Calibration curve of $\mathrm{SCN}^{-}$

Table 1. Percentage recoveries of thiocyanate

\begin{tabular}{lcc}
\hline Test sample & \% recovery & \% RSD \\
\hline Fresh dried bean & 98.91 & 4.02 \\
Sprouted bean & 92.97 & 5.01 \\
Fresh flour & 99.80 & 3.65 \\
Cooked flour & 95.65 & 4.21 \\
Green leaves & 90.01 & 5.00 \\
\hline
\end{tabular}

Table 2. Mean rates of thiocyanate $(\mathrm{mg} / \mathrm{kg})$ in the treated beans

\begin{tabular}{|c|c|c|c|}
\hline \multirow[b]{2}{*}{$\begin{array}{l}\text { Variety/ } \\
\text { treatment }\end{array}$} & \multicolumn{2}{|c|}{ Concentration in $(\mathrm{mg} / \mathrm{kg})$} & \multirow[b]{2}{*}{ P-value } \\
\hline & $\begin{array}{c}\text { Red mean } \pm \text { SE } \\
\text { (range) }\end{array}$ & $\begin{array}{c}\text { Brown mean } \pm \mathrm{SE} \\
\text { (range) }\end{array}$ & \\
\hline $\begin{array}{l}\text { Fresh dried } \\
n=8\end{array}$ & $\begin{array}{c}43.48 \pm 1.56^{\mathrm{b}} \\
(39.11-47.85)\end{array}$ & $\begin{array}{c}31.83 \pm 1.88^{\mathrm{b}} \\
(26.57-37.09)\end{array}$ & 0.471 \\
\hline $\begin{array}{l}\text { Sprouted } \\
\mathrm{n}=8\end{array}$ & $\begin{array}{c}39.93 \pm 0.89^{\mathrm{b}} \\
(37.44-42.42)\end{array}$ & $\begin{array}{c}53.30 \pm 0.78^{c} \\
(51.12-55.48)\end{array}$ & $<0.001$ \\
\hline $\begin{array}{l}\text { Soaked } \\
n=24\end{array}$ & $\begin{array}{c}10.5 \pm 1.73^{\mathrm{a}} \\
(2.02-18.98)\end{array}$ & $\begin{array}{c}9.73 \pm 1.72^{\mathrm{a}} \\
(1.31-18.15)\end{array}$ & 0.718 \\
\hline $\mathrm{P}$-value & $<0.001$ & 0.015 & \\
\hline
\end{tabular}

Mean values followed by the same small letter(s) within the same column or same row are not remarkably different $(\alpha=0.05$, SNKtest). $\mathrm{a}<\mathrm{b}<\mathrm{c}$ 
Table 3. Mean Levels of thiocyanate $(\mathrm{mg} / \mathrm{kg})$ in finger millet beans immersed at different times

\begin{tabular}{lcc}
\hline $\begin{array}{c}\text { Soaking time } \\
\text { (minutes) }\end{array}$ & $\begin{array}{c}\text { Concentration in }(\mathbf{m g} / \mathbf{k g}) \\
\text { Red }(\text { Mean } \pm \text { SE) } \\
(\text { Range) } \mathbf{n}=\mathbf{8}\end{array}$ & $\begin{array}{c}\text { Brown }(\text { Mean } \pm \text { SE) } \\
(\text { Range }) \mathbf{n}=\mathbf{8}\end{array}$ \\
\hline 0 & $26.35 \pm 0.45^{\mathrm{c}}$ & $22.31 \pm 0.34^{\mathrm{c}}$ \\
30 & $18.45 \pm 0.63 \mathrm{~b}$ & $15.62 \pm 0.74 \mathrm{~b}$ \\
& $(13.2-18.98)$ & $(14.3-18.15)$ \\
60 & $8.24 \pm 0.32 \mathrm{a}$ & $8.49 \pm 0.41 \mathrm{a}$ \\
& $(5.23-9.6)$ & $(7.08-9.02)$ \\
900 & $4.81 \pm 0.99 \mathrm{a}$ & $5.10 \pm 1.34 \mathrm{a}$ \\
& $(2.02-7.6)$ & $(1.31-8.89)$ \\
p-value & $<0.001$ & $<0.001$ \\
\hline
\end{tabular}

From Table 2, thiocyanate rates in the beans of the red and brown finger millet were within safe rates $(100 \mathrm{mg} / \mathrm{kg})$. The rates of thiocyanate were from $43.48 \pm 1.56$ to $10.5 \pm 1.56 \mathrm{mg} / \mathrm{kg}$ in the red finger millet with fresh dried finger millet having the highest and the immersed one having the lowest, while for brown finger millet the rates ranged from $53.30 \pm 0.78$ to $9.73 \pm 1.72 \mathrm{mg} / \mathrm{kg}$. There was a statistically remarkable dissimilarity between the immersed and fresh dried beans, and between immersed and germinated in red finger millet and there was a remarkable dissimilarity between the fresh dried, germinated and immersed beans in the brown finger millet. Sprouted treatment showed a remarkable dissimilarity between the brown variety and the red variety $(\mathrm{P}<0.001$ at $95 \%$ confidence level). This could be accredited to varietal dissimilarities such as the brand and endosperm contexture of the beans and metabolic breakdown of thiocyanate in the plant. The germinated brown beans recorded the biggest rates of thiocyanate followed by the fresh dried beans and the immersed beans had the smallest amount. The rise of thiocyanate during germinating could have been brought about by the enzymes which are active in the shoots during the young growing stages of the plant (Chweya 1990). The rates of thiocyanate in the fresh dried beans could be due to the fact that thiocyanate in millet is contained in the brand and endosperm portions of the seeds (Klopfenstein et al. 2012).

The rates of thiocyanate in the fresh dried and in the germinated beans were higher as confronted to the rates present in other foods such as cassava $(12.95 \mathrm{mg} / \mathrm{kg})$, cabbages (23 mg/kg) (Chandra et al. 2004) and pearl millet (35 mg/kg) (Gaitan et al. 1989). Therefore, frequent consumption of fresh dried and germinated finger millet beans could cause accruement of thiocyanate in the body. Previous studies discovered that the issue of production of cyanogenic glycoside (dhurrin) from sorghum during germinating is governable. Secondly, the glycoside and the dhurrin-synthesizing enzyme are mostly situated in the coleoptile, in a young shoot. This indicates that omission of the shoots after germination may help to assist thiocyanate (Chove and Mamiro 2010).

Table 3 shows the influence of various immersing time on thiocyanate proportion. In Table 3 , mean values followed by the same small letter(s) within the same column or row are not remarkably different $(\alpha=0.05$, SNKtest). Table 3 shows that immersing decreased thiocyanate level in red finger millet from $26.45 \pm 0.45$ to $4.81 \pm 0.99$ $\mathrm{mg} / \mathrm{kg}$ for 900 minutes of immersing and from $22.31 \pm 0.34$ to $5.10 \pm 1.34 \mathrm{mg} / \mathrm{kg}$ for brown finger millet for the same immersing duration. There was a decrease in thiocyanate after an hour of immersing from $26.45 \pm 0.45$ to $8.24 \pm 0.32$ $\mathrm{mg} / \mathrm{kg}$ in the red variety and from $22.31 \pm 0.34$ to $8.49 \pm 0.41$ $\mathrm{mg} / \mathrm{kg}$ for brown finger millet after the same period of immersing. Various immersing time remarkably decreased the rates of thiocyanate $(p<0.001)$, with longer immersing time (900 minutes) decreasing thiocyanate proportion to low rates, $4.81 \pm 0.99$ and $5.10 \pm 1.34 \mathrm{mg} / \mathrm{kg}$ for the red and brown variety respectively. There was no remarkable dissimilarity between immersing for 60 and 900 minutes in both the varieties. This decrease indicated that thiocyanate is soluble in water and is leached away when draining water (Soetan and Oyewole 2009). Soaking in water increases detoxification as cells are broken by osmosis and fermentation which facilitates hydrolysis of the glycosides. Longer immersing times (18 to 24 hours) can decrease cyanide rates by up to $50 \%$. For example, a study on cassava roots immersed for 3 days led to decrease of cyanide from 25.5 to $19.4 \mathrm{mg} / \mathrm{kg}$ (FAO 2005). Processing of millet showed that combination of drying and immersing was more effective in decreasing thiocyanate rates than drying alone.

\section{Rates of thiocyanate in finger millet flour}

Levels of thiocyanate in the fresh, fermented and cooked flour of the red and brown finger millet are shown in Table 4. Table 4 shows that thiocyanate in the fresh, fermented and cooked flour of the red and brown finger millet was within safe rates. The rates in fresh flour ranged from $20.54 \pm 1.39$ in the red variety to $24.50 \pm 1.83 \mathrm{mg} / \mathrm{kg}$ in the brown variety. In fermented flour, the rates ranged from $19.43 \pm 1.37$ in the brown variety to $20.03 \pm 0.87 \mathrm{mg} / \mathrm{kg}$ in the red variety. Levels in cooked flour ranged from $4.28 \pm 0.50$ to $4.96 \pm 0.40 \mathrm{mg} / \mathrm{kg}$ in the red and brown varieties, respectively. Cooked flour had the lowest thiocyanate level, followed by fermented then fresh flour in both varieties. Independent $\mathrm{t}$-test indicated that there was no remarkable dissimilarity between the varieties $(\mathrm{P}>0.05$ at $95 \%$ confidence level). This implies that consuming any of the two varieties results in absorbing relatively the same amount of thiocyanate. Levels of thiocyanate in the fresh flour varied remarkably from the rates present in the cooked flour $(\mathrm{P}<0.001)$. There was a remarkable dissimilarity between the rates of thiocyanate in fermented flour and in the cooked flour. Levels of thiocyanate in the fresh flour did not vary remarkably from the rates in the fermented flour.

The thiocyanate proportion was slightly decreased during fermentation though not remarkable. This was due to the fact that fermentation inactivated the enzyme myrosinase thus decreasing the total thiocyanate proportion plus also the utilization of glucose and sulfur moieties of the compounds by microbial enzymes (Vig and Walia 2001). It is believed that some cyanidrophilic tolerant micro-organisms influence the breakdown of the cyanogenic glycosides (Tewe 2003). Fermented flour had enough time for their bond thiocyanate to be hydrolyzed by 
the enzymes and thus allocated to various forms (Asegbeloyin and Onyimonyi 2007).

Cooking led to higher decrease thus appeared to be the most effective method of decreasing thiocyanate proportion. This was partly due to the heat-sensitive nature of the active principle and the fact that cooking devastates active enzymes included in thiocyanate composition at about $72^{\circ} \mathrm{C}$. This can also be accredited to the previous processing steps such as drying and grinding. Previous studies showed that drying and cooking, immersing and cooking decreased rates of thiocyanate than cooking alone (Tewe 2003). Heat treatment negatively influences glucosinolates proportion, wet heating/pressure cooking is more effective over dry heating (Jensen et al. 2001). Earlier studies showed that microwaving decreases the average thiocyanate result to one-half; steaming decreases this result to one-third. The influence of microwaving and steaming is dependent on the individual's intestinal flora and is thus highly varied, whereas the influence of boiling is more reliable and constant (Master 2008). Levels of thiocyanate gained in various cooking time are introduced in Table 5.

From Table 5, the rates of thiocyanate in cooked flour were from $8.78 \pm 0.40$ to $1.56 \pm 0.74 \mathrm{mg} / \mathrm{kg}$ in the red variety when cooking time varied from 5 to 30 minutes, while the rates in the brown variety were from $8.92 \pm 0.37$ to $1.85 \pm 0.63 \mathrm{mg} / \mathrm{kg}$ for the same cooking duration. There was a remarkable dissimilarity in the rates of thiocyanate when cooking time varied from 5 minutes, to 10 and 30 minutes respectively $(\mathrm{P}<0.001)$. Cooking for 30 minutes lowered thiocyanate to very low rates implying that longer cooking time could be a sure way of decreasing the rates of thiocyanate. Cooking for a short time will require inclusion of a previous treatment like immersing or sun-drying of the beans. Hydrolysis of cyanogenic glycosides yields hydrogen cyanide which was driven off during boiling. Free thiocyanate was quickly lost in boiling water (Tewe 2003; Adamafio and Ankrah 2009).

\section{Rates of thiocyanate in the green and dried leaves of finger millet}

Rates of thiocyanate in the green and dried leaves from the red and brown finger millet are shown in Table 6. From Table 6 , it can be concluded that mean rates of thiocyanate in the green leaves were from $30.78 \pm 0.40$ for the red variety to $31.69 \pm 0.71 \mathrm{mg} / \mathrm{kg}$ for the brown variety. Levels in the dried leaves were from $9.00 \pm 0.13$ in the red variety to $8.80 \pm 0.14 \mathrm{mg} / \mathrm{kg}$ in the brown variety. There was an important dissimilarity in the thiocyanate proportion of the green and dried leaves of the red and brown finger millet $(\mathrm{P}<0.001)$.

Table 6. Mean rates of thiocyanate $(\mathrm{mg} / \mathrm{kg})$ in the green and dried leaves of the red and brown finger millet

\begin{tabular}{lcc}
\hline \multicolumn{1}{c}{ Treatment } & $\begin{array}{c}\text { Red } \\
\text { Mean } \pm \text { SE (Range) } \\
\mathbf{n = 8}\end{array}$ & $\begin{array}{c}\text { Brown } \\
\text { Mean } \pm \text { SE (Range) } \\
\mathbf{n}=\mathbf{8}\end{array}$ \\
\hline Green leaves & $30.78 \pm 0.40^{\mathrm{b}}$ & $31.69 \pm 0.71^{\mathrm{b}}$ \\
& $(28.88-32.56)$ & $(28.80-34.05)$ \\
Dried leaves & $9.00 \pm 0.13^{\mathrm{a}}$ & $8.80 \pm 0.14^{\mathrm{a}}$ \\
& $(8.35-9.4)$ & $(8.25-9.15)$ \\
p-value & $<0.001$ & $<0.001$ \\
\hline
\end{tabular}

Mean values followed by the same small letter(s) within the same column or row are not remarkably different $(\alpha=0.05$, SNK-test).

Table 4. Mean Levels of thiocyanate $(\mathrm{mg} / \mathrm{kg})$ in treated finger millet flour

\begin{tabular}{|c|c|c|c|}
\hline \multirow[t]{2}{*}{ Treatment } & \multicolumn{2}{|c|}{ Concentration in (mg/kg) } & \multirow[t]{2}{*}{ P-value } \\
\hline & Red Mean \pm SE (Range) $n=24$ & Brown Mean \pm SE (Range) $n=24$ & \\
\hline Fresh flour & $20.54 \pm 1.39^{\mathrm{b}}(13.73-27.35$ & $24.50 \pm 1.83^{\mathrm{b}}(15.53-33.47)$ & 0.088 \\
\hline Fermented flour & $20.03 \pm 0.87^{\mathrm{b}}(15.77-24.29)$ & $19.43 \pm 1.37^{\mathrm{b}}(12.72-26.14)$ & 0.713 \\
\hline Cooked flour & $4.28 \pm 0.50^{\mathrm{a}}(1.23-9.89)$ & $4.96 \pm 0.40^{\mathrm{a}}(1.79-10.21)$ & 0.513 \\
\hline P-value & 0.001 & $<0.001$ & \\
\hline
\end{tabular}

Note: Mean values followed by the same small letter(s) within the same column or row are not remarkably different $(\alpha=0.05$, SNK-test)

Table 5. Mean rates of thiocyanate $(\mathrm{mg} / \mathrm{kg})$ in flour, cooked for 5, 10 and 30 minutes

\begin{tabular}{lccccc}
\hline \multicolumn{1}{c}{ Variety/ cooking time } & & \multicolumn{2}{c}{ Concentration in $\mathbf{~ m g / k g}$} & \multicolumn{2}{c}{ P-value } \\
& Levels before cooking & $\mathbf{5}$ mins & $\mathbf{1 0}$ mins & $\mathbf{3 0}$ mins & \\
\hline & $20.54 \pm 1.39^{\mathrm{d}}$ & $8.78 \pm 0.40^{\mathrm{c}}$ & $2.51 \pm 0.20^{\mathrm{b}}$ & $1.56 \pm 0.74^{\mathrm{a}}$ & $<0.001$ \\
Red & $(13.73-27.35)$ & $(6.58-9.89)$ & $(1.89-3.30)$ & $(1.23-3.29)$ & \\
Mean $\pm \mathrm{SE}$ & & & & & \\
(Range) $\mathrm{n}=8$ & & & & & \\
Brown & $24.50 \pm 1.83^{\mathrm{d}}$ & $8.92 \pm 0.37^{\mathrm{c}}$ & $4.10 \pm 0.26^{\mathrm{b}}$ & $1.85 \pm 0.63^{\mathrm{a}}$ & $<0.001$ \\
Mean $\pm \mathrm{SE}$ (Range) $\mathrm{n}=8$ & $(15.53-33.47)$ & $(6.85-10.21)$ & $(2.9-4.9)$ & $(1.79-3.02)$ & \\
\hline
\end{tabular}

Note: Mean values followed by the same small letter(s) within the same column or row are not remarkably different $(\alpha=0.05$, SNK-test). $\mathrm{a}<\mathrm{b}<\mathrm{c}<\mathrm{d}$ 
The green leaves bore the highest proportion of thiocyanate in both varieties while the dried leaves bore the lowest. It is therefore preferable that farmers should feed their animals with the dried leaves of finger millet which contain lower thiocyanate proportion and not the green leaves. The high thiocyanate proportion in green leaves could be accredited to the enzymes which were once active in the growing stages of plants but became inactive during drying. It has also been disclosed that environmental conditions and agronomic factors such as plant density and nitrogen fertilizer application influence the thiocyanate rates in kale leaves (Chweya 1990). Previous studies on cyanide potential of sorghum assured that after flowering, HCN maybe only $10 \%$ left of its initial rates at young age and vegetative and thus farmers are motivated to wait till maturity in order to feed their animals with sorghum (Wheeler and Mulcathy 1989; Ilza and Pinotti 2000).

In conclusion, all the forms of examined finger millet were discovered to have contents of thiocyanate within safe rates. The fresh dried and germinated bean samples of the red and brown finger millet showed higher thiocyanate mean rates than those shown by the immersed beans. Germinating brown finger millet remarkably raised the thiocyanate rate, therefore individuals willing to utilize germinated finger millet must be confirmed to immerse the grains first and then dry them properly before the process of fermentation and cooking is carried out to lower the thiocyanate proportion. Immersing within 900 minutes substantially reduced the thiocyanate proportion in finger millet to relatively low amounts. Cooking was discovered to be a powerful method of decreasing the proportion of thiocyanate to appropriate rates of normal consumption, particularly when the cooking time was lengthened for 30 minutes. Since the rates of thiocyanate were higher in the green leaves than that in the dried leaves, thus farmers should feed their cattle with the dried leaves.

\section{REFERENCES}

Adamafio N, Ankrah A. 2009. Cyanogenic glycoside content of fresh and processed peels of four improved Ghanaian cassava cultivars. Ghanaian J Sci 49: 855-1448.

Adwok JA. 2006. Thyroid I Endemic goiter-the Ptolemy project. http: //www.ptolemy.Ca/members/archives/2006/Endemic Goiter.htm. [20 August 2012]

Asegbeloyin JN, Onyimonyi AE. 2007. The effect of different processing methods on the residual cyanide content of ' $G$ '. Pak J Nutr 6: 163 166. DOI: $10.3923 /$ pjn.2007.163.166

Cardoso AP, Ernesto M, Nicala D, Mirione E, Chavane L, N'zwalo H, Chikumba S, Cliff J, Paulo A, Haque RM, Bradbury JH. 2004 Combination of cassava flour cyanide and urinary thiocyanate measurements of school children in Mozambique. Intl J Food Sci Nutr 55: 183-190. DOI: 10.1080/09637480410001725265

Chandra AK, Sanjukta M, Lahari D, Tripathy S. 2004. Goitrogenic content of Indian Cyanogenic plant foods \& their in vitro antithyroidal activity. Indian J Med Res 119: 180-185.

Chove B, Mamiro P. 2010. Effect of germination and autoclaving of sprouted finger millet and kidney beans on cyanide content. Tanzania J Health Res 12: 1-6. DOI: 10.4314/thrb.v12i4.51262

Chweya JA. 1990. Contents of nitrate-N and thiocyanate ions in kale (Brassica oleracea var. acephala. DC) leaves from kale-growing areas in Kenya. Plant Soil Sci 218: 181-190. DOI: 10.17660/ActaHortic. 1988.218.23

Elnour A, Hambraeous L, Eltom M, Bourdoux P. 2000. Endemic goiter with iodine sufficiency: a possible role for the consumption of Pearl millet in the etiology of endemic goiter. Amer J Clin Nutr 71: 59-66. DOI: $10.1093 / \mathrm{ajcn} / 71.1 .59$

EURACHEM Guide. 1998. The fitness for purpose of Analytical Methods. A laboratory guide to method validation and related topics. www.eurachem.org/index.php/guides. [12 February 2013]

FAO. 2005. Kenya Nutrition Profile-Food and Nutrition. FAO, Rome.

Gaitan E, Lindsay R, Cooksey RC. 1989. Environmental Goitrogenesis. In: Gaitan E (ed.). Environmental Goitrogenesis. CRC, Boca Raton, US.

ICRISAT. 2011. ICRISAT Happenings. http: //www.icrisat.org/happenings $1482 \mathrm{htm}$. [12 February 2013]

Ilza AF, Pinotti PM. 2000. Cyanogenic glycosides in plants. Brazilian Arch Biotechnol 43: 487-492. DOI: 10.1590/S151689132000000500007

Jensen CR, Mogensen VO, Mortensen G, Fieldsend JK, Milford G, Anderson MN. 2001. Seed glucosinolate, oil protein content of fieldgrown rape (Brassica L.) affected by soil drying and evaporative demand. Field Crops Res 47: 93-105. DOI: 10.1016/03784290(96)00026-3

Klopfenstein CF, Hoseney RC, Leopold HW. 2012. Goitrogenic effects of pearl millet. Intl Nutr Represent 27: 1039-1047.

Makokha AO 2002. Malting characteristics of some sorghum (Sorghum bicolor) and finger millet (Eleusine coracana) grain varieties grown in Kenya. [Dissertation]. Jomo Kenyatta University of Agriculture and Technology, Kenya.

Master JC. 2008. Thyroid toxins: Double-Edged Swords of Kingdom Plantae 1: 30-35.

Mbithi-Mwikya S, Van Camp J, Mamiro P, Ooghe W, Kolsteren P, Huyghebaert A. 2002. Evaluation of nutritional characteristics of a finger millet-based complementary food. J Agric Chem 50: 30303036. DOI: 10.1021/jf011008a

Narwal RP, Dahiya RR, Malik RS. 2013. Pollutant elements in soilplants- Animal system in India and future thrust Areas. Eur Chem Bull 2: 38-45. DOI: 10.17628/ecb.2013.2.38-45

Ocheme OB. 2007. Effects of millet flour on the quality and acceptability of millet flour porridge. J Food Technol 5: 215-219.

Onyeka U, Dibia I. 2002. Malted food made from maize, soybean, ground and banana. J Food Sci Agric 82: 513-516. DOI: 10.1002/jsfa.1060

Peter D. 1992. The elusive Granary: Herder, farmer and state in Northern Kenya. African Stud Ser 73: 9-20.

Saidu Y. 2004. Physicochemical features of rhodanese. African J Biotechnol 3: 370-374. DOI: 10.5897/AJB2004.000-2071

Soetan KO, Oyewole OE. 2009. The need for adequate processing to reduce the anti-nutritional factors in plants used as human foods and animal foods: A review. Afr J Food Sci 3: 223-232.

Tatham AS, Fido RJ, Moore CM, Kasardat DD, Kuzmickyt DD, Keen JN, Shewry PR. 1996. Characterisation of the major prolamin of Tef (Eragrostis tef) and finger millet (Eleusine coracana). J Cereal Sci 24: 65-71. DOI: $10.1006 /$ jers. 1996.0038

Tewe OO. 2003. Detoxification of cassava products and effects of residual toxins on consuming animals. http: //www.fao.org/docrep/003. [31 October 2003].

Toure F, Lucas E, Stoecker B. 2003. Fish and shrimp added bioavailable iodine to cassava and millet-based diets. Ecol Food Nutr 42: 223-239. DOI: $10.1080 / 0367024029226196$

Traor'e T, Mouquet C, Icard-Vernière C, Traoré A, Trèche S. 2004. Changes in nutrient composition, phytate and cyanide contents and $\alpha$ amylase activity during cereal malting in small production units in Ouagadougou (Burkina Faso). Food Chem 88: 105-114. DOI: 10.1016/j.foodchem.2004.01.032

Vig AP, Walia A. 2001. Beneficial effects of Rhizopus oligosporus fermentation on reduction of glucosinolates, fibre in rapeseed. Bioresour Technol 78: 309-312. DOI: 10.1016/S09608524(01)00030-X

Wheeler JL, Mulcathy C. 1989. Consequences for animal cyanogenesis in sorghum forage and hay - A Review. Trop Grasslands 23: 193-196. 